\title{
АНАЛІЗ МАТЕРИНСЬКИХ ЧИННИКІВ ПЕРИНАТАЛЬНОЇ ПАТОЛОГІЇ СЕРЕД ЖІНОК 3 ПОРУШЕННЯМ МЕНСТРУАЛЬНОГО ЦИКЛУ
}

\author{
ANALYSIS OF MATERNAL FACTORS OF THE PERINATAL \\ PATHOLOGIES AMONG WOMEN WITH MENSTRUAL CYCLE \\ DISORDER
}

\section{Олександра Маланчук (Oleksandra Malanchuk) ${ }^{1}$ \\ 1 Державна Установа «Інститут спадкової патології НАМН України», Львів, Україна (State Institution "Institute of Heritable Pathology of the National Academy of Medical Sciences of Ukraine")}

Summary. The analysis of the course, completion of pregnancy in women with reproductive losses and menstrual irregularities, the formation of risk groups with the aim of improving the prevention system, early diagnosis of perinatal pathology and predicting healthy offspring was carried out.

Keywords: menstrual cycle, perinatal pathology, reproductive function.

Вступ. За останні роки перинатальна патологія виросла в проблему, яка має не менше значення в медицині, ніж проблеми серцево-судинних, онкологічних і психічних захворювань. Частота мертвонародження і смертності немовлят в перший тиждень після пологів залишається високою. Перинатальна патологія займає перше місце у структурі дитячої смертності в Україні і складає 35-40\%. Перинатальна смертність сягає 8,1, а мертвонароджуваність - 4,6 на 1000 усіх народжених [7,14].

Репродуктивний період тісно пов'язаний з появою місячних $[2,3,13]$.

Менструальний цикл - це складний біологічний процес в організмі жінки, спрямований на репродукцію і підготовку організму до вагітності. Нормальна менструальна функція здійснюється внаслідок правильної синхронної взаємодії важливих ланок нейроендокринної регуляції на різних рівнях $[5,6,8,14]$. 
Порушення менструальної функції можуть викликати такі причини: психічні і нервові захворювання, емоційно-нервові порушення; порушення харчування, авітамінози, ожиріння різної етіології; професійні шкідливості (дія деяких хімічних речовин, радіоактивне випромінювання); інфекційні і септичні захворювання, гонорея, туберкульоз, паразитарні захворювання; захворювання серцево-судинної і кровотворної систем, печінки та ін.; гінекологічні операції; травми сечостатевих шляхів (фістули); вікові порушення розвитку гіпоталамогіпофізарної ділянки статевого дозрівання; інволюційна перебудова гіпоталамічних центрів в пременопаузі.

Порушення менструальної функції можуть виникати в різні періоди життя жінки: під час статевого дозрівання, в період статевої зрілості; в пременопаузі $[3,14]$. Залежно від клінічних проявів, ці порушення поділяють на три основні групи:

1. Аменорея (відсутність менструації протягом 6 місяців і більше) i гіпоменструальний синдром.

2. Порушення менструального циклу, що проявляються циклічними i ациклічними кровотечами (мено- і метрорагіями).

3. Болючі менструації (альгодисменорея) можуть мати як функціональний, так i органічний характер.

У відповідь на вагітність в організмі жінки відбуваються фізіологічні адаптаційні перебудови у зв'язку з підвищеним перевантаженням на низку органів і систем. Межі збільшення або зниження адаптативних реакцій забезпечують необхідний гомеостаз у системі “мати-плацента-плід”. Враховуючи напруженість механізмів адаптації організму матері під час вагітності та наявність факторів, здатних негативно вплинути на перебіг вагітності, формуються ускладнення гестації та пологів, які супроводжуються дезадаптацією в системі “мати-плацента-плід” і як наслідок порушенням функціонального стану і розвитку плода $[11,17,18]$.

У структурі антенатальної охорони плода протягом усього терміну гестації, плід є об'єктом турботи про стан його здоров'я [12]. Спостереження за 
станом здоров’я плода є складним і до кінця не вирішеним питанням, як 3 медичних i 3 технічних аспектів, так i 3 етичних міркувань. Ефективне спостереження за станом здоров’я плода вимагає вдосконалення програми пренатальної діагностики з урахуванням технологічних та етичних аспектів. При цьому, ефективне запобігання перинатальних втрат потребує профілактичних заходів задовго до народження дитини в межах програми преконцепційної профілактики $[1,4,9,10,15,16]$.

Мета. Вище наведені дані літератури послужили причиною, дослідити материнські чинники перинатальних ускладнень з порушенням менструального циклу у жінок Львівщини.

Матеріали та методи. Проаналізовано результати перебігу та завершення вагітності у 107 жінок з порушенням менструального циклу, проведено їх порівняння 3 аналогічними показниками у 100 жінок контрольної групи. Проводилось вивчення первинної документації та формування потоку пацієнтів для медико-генетичного консультування в умовах Львівського медикогенетичного центру (МГЦ). Використовувались клінічні, медико-статистичні, інструментальні, лабораторні методи обстеження.

Результати та обговорення. Були сформовані дві групи жінок: I група 107 жінок з репродукційними втратами та порушенням менструального циклу (основна), II група - 100 жінок без порушеного репродукційного анамнезу та менструального циклу, які народили здорових дітей (контрольна).

Встановлено, що у 72,9\% жінок основної групи та у 62,0\% контрольної спостерігався ускладнений перебіг вагітності $(\mathrm{P}>0,05)$. Серед нозологічного спектру ускладнень перебігу вагітності жінок основної групи: 14,1\% становить загроза переривання I половини вагітності, по 7,5\% - ранній гестоз та загроза перериванні II половини вагітності, по 5,6\% - прееклампсія та ранній гестоз + анемія, по 4,7\% - анемія, ранній гестоз + прееклампсія, ранній гестоз + загроза переривання I половини вагітності, багатовіддя, по 3,7\% - прееклампсія + анемія, прееклампсія + загроза переривання I i II половини вагітності, загроза переривання II половини вагітності + анемія, 2,8\% - маловіддя (табл.1). 
Таблиця 1. Характеристика перебігу вагітності у жінок з репродукційними втратами та порушенням менструального циклу.

\begin{tabular}{|c|c|c|c|c|c|}
\hline \multirow[t]{2}{*}{ Показники } & \multicolumn{2}{|c|}{ Основна група } & \multicolumn{2}{|c|}{$\begin{array}{l}\text { Контрольна } \\
\text { група }\end{array}$} & \multirow[t]{2}{*}{$\begin{array}{c}\text { Статистичні } \\
\text { показники } \\
\end{array}$} \\
\hline & Абс. & $\%$ & Абс. & $\%$ & \\
\hline $\begin{array}{l}\text { Загроза перериваня I половини } \\
\text { вагітності }\end{array}$ & 15 & 14,1 & 8 & 8,0 & $\begin{array}{c}\chi^{2}=1,896, p=0,169 \\
p>0,05\end{array}$ \\
\hline $\begin{array}{l}\text { Загроза переривання II } \\
\text { половини вагітності }\end{array}$ & 8 & 7,5 & 4 & 4,0 & $\begin{array}{c}\chi^{2}=1,144, p=0,285 \\
p>0,05\end{array}$ \\
\hline Ранній гестоз & 8 & 7,5 & 4 & 4,0 & $\begin{array}{l}\chi^{2}=1,144, p=0,285 \\
p>0,05\end{array}$ \\
\hline Анемія вагітних & 5 & 4,7 & 5 & 5,0 & $\begin{array}{c}\chi^{2}=0,012, p=0,913 \\
p>0,05\end{array}$ \\
\hline Прееклампсія & 6 & 5,6 & 10 & 10,0 & $\begin{array}{c}\chi^{2}=1,398, p=0,237 \\
p>0,05\end{array}$ \\
\hline Ранній гестоз+анемія & 6 & 5,6 & 5 & 5,0 & $\begin{array}{c}\chi^{2}=0,038, p=0,846 \\
p>0,05\end{array}$ \\
\hline Ранній гестоз+прееклампсія & 5 & 4,7 & 4 & 4,0 & $\begin{array}{c}\chi^{2}=0,056, p=0,813 \\
p>0,05\end{array}$ \\
\hline Прееклампсія+анемія & 4 & 3,7 & 3 & 3,0 & $\begin{array}{c}\chi^{2}=0,086, p=0,770 \\
p>0,05\end{array}$ \\
\hline $\begin{array}{l}\text { Ранній гестоз+ загроза } \\
\text { переривання I половини }\end{array}$ & 5 & 4,7 & 7 & 7,0 & $\begin{array}{c}\chi^{2}=0,513, p=0,475 \\
p>0,05\end{array}$ \\
\hline $\begin{array}{l}\text { Загроза переривання II } \\
\text { половини+анемія }\end{array}$ & 4 & 3,7 & 4 & 4,0 & $\begin{array}{c}\chi^{2}=0,010, p=0,923 \\
p>0,05\end{array}$ \\
\hline $\begin{array}{l}\text { Прееклампсія+ загроза } \\
\text { переривання I і II половини }\end{array}$ & 4 & 3,7 & 3 & 3,0 & $\begin{array}{c}\chi^{2}=0,086, p=0,770 \\
p>0,05\end{array}$ \\
\hline Багатовіддя & 5 & 4,7 & 3 & 3,0 & $\begin{array}{c}\chi^{2}=0,389, p=0,533 \\
p>0,05\end{array}$ \\
\hline Маловіддя & 3 & 2,8 & 2 & 2,0 & $\begin{array}{c}\chi^{2}=0,142, p=0,707 \\
p>0,05\end{array}$ \\
\hline Ускладнений перебіг вагітності & 78 & 72,9 & 62 & 62,0 & $\begin{array}{c}\chi^{2}=2,804, p=0,095 \\
p>0,05\end{array}$ \\
\hline $\begin{array}{l}\text { Неускладнений перебіг } \\
\text { вагітності }\end{array}$ & 29 & 27,1 & 38 & 38,0 & $\begin{array}{c}\chi^{2}=2,804, p=0,095 \\
p>0,05\end{array}$ \\
\hline Всього & 107 & 100 & 100 & 100 & \\
\hline
\end{tabular}

У жінок контрольної групи найбільшу частку становила: 8,0\% - загроза переривання I половини вагітності і 7,0\% - поєднання раннього гестозу та загрози переривання I половини вагітності. Порівняння даних нозологічного 
спектру ускладнень у жінок основної та контрольної груп не виявили значущих відмінностей (табл. 1, Р>0,05).

Таблиця 2. Паритет вагітності у жінок, що вивчались 3 порушенням менструального циклу.

\begin{tabular}{|c|c|c|c|c|c|c|}
\hline \multirow[t]{2}{*}{ Група } & \multirow{2}{*}{$\begin{array}{c}\text { Кількіст } \\
\text { ь жінок } \\
\text { абс./ \% }\end{array}$} & \multicolumn{5}{|c|}{$\begin{array}{c}\text { Показники } \\
\text { абс./ \% }\end{array}$} \\
\hline & & 0 ваг. & I ваг. & II ваг. & III ваг. & $\begin{array}{l}\text { IV ваг. i } \\
\text { більше }\end{array}$ \\
\hline Основна & $107 / 100$ & $19 / 17,7$ & $21 / 19,6$ & $25 / 23,4$ & $17 / 15,9$ & $25 / 23,4$ \\
\hline $\begin{array}{l}\text { Контроль } \\
\text { на }\end{array}$ & $100 / 100$ & - & - & $86 / 86$ & $9 / 9$ & $5 / 5$ \\
\hline \multicolumn{2}{|c|}{$\begin{array}{l}\text { Статистичні } \\
\text { показники }\end{array}$} & $\begin{array}{l}\chi^{2}=19,552 \\
P<0,001 \\
P<0,05\end{array}$ & $\begin{array}{l}\chi^{2}=21,842 \\
P<0,001 \\
P<0,05\end{array}$ & $\begin{array}{l}\chi^{2}=81,546 \\
P<0,001 \\
P<0,05\end{array}$ & $\begin{array}{l}\chi^{2}=2,233 \\
P=0,136 \\
P>0,05\end{array}$ & $\begin{array}{l}\chi^{2}=14,068 \\
P<0,001 \\
P<0,05\end{array}$ \\
\hline
\end{tabular}

Як видно 3 даних таблиці 2, встановлено достовірні відмінності між показниками паритету вагітності у жінок основної та контрольної груп для вагітних вперше та IУ і більше разів $(\mathrm{P}<0,05)$. Так, у $21(19,6 \%)$ жінок з основної групи ризику дана вагітність була першою за рахунком, у 25 (23,4\%) 3 них другою, у 17 (15,9\%) - третьою, у 25 (23,4\%) були вагітними у 4 та більше рази. У 19 (17,7\%) жінок вагітність не наступала (непліддя). В той же час в контрольній групі 86 (86,0\%) жінок - були вагітними вдруге, 9 (9,0\%) жінок були вагітними у III та 5(5,0\%) у IV рази.

Аналізуючи показники таблиці 3 виявлено, що серед 33,7\% жінок основної групи родів не було, перші роди відмічались у 25,2\%, повторні - у 41,1\% жінок. У всіх жінок контрольної групи роди були повторними. Тобто достовірно частіше жінки 3 порушенням менструального циклу не народжували або народжували вперше $(\mathrm{P}<0,05)$. При аналізі даних про завершення вагітності встановлено більший відсоток родорозрішень шляхом кесарського розтину у жінок основної групи, що становив 42,3\% у порівнянні 3 19,0\% жінок 
контрольної групи $(\mathrm{P}>0,05)$. Фізіологічні пологи становили 57,7\% у жінок основної групи та 81,0\% - контрольної групи $(\mathrm{P}<0,05)$.

Таблиця 3. Характеристика завершення вагітності у жінок з репродукційними втратами та порушенням менструального циклу.

\begin{tabular}{|c|c|c|c|c|c|c|}
\hline Група & $\begin{array}{c}\text { Кількість } \\
\text { жінок } \\
\text { абс./ } \%\end{array}$ & \multicolumn{5}{|c|}{$\begin{array}{l}\text { Показники } \\
\text { абс./ \% }\end{array}$} \\
\hline & & $\begin{array}{l}\text { Родів не } \\
\text { було }\end{array}$ & Роди перші & $\begin{array}{l}\text { Роди } \\
\text { повторні }\end{array}$ & $\begin{array}{l}\text { Роди } \\
\text { Фізіологічні }\end{array}$ & $\begin{array}{l}\text { Кесарський } \\
\text { розтин }\end{array}$ \\
\hline Основна & $107 / 100$ & $36 / 33,7$ & $27 / 25,2$ & $44 / 41,1$ & $41 / 57,7$ & $30 / 42,3$ \\
\hline Контрольна & $100 / 100$ & - & - & $100 / 100$ & $81 / 81$ & $19 / 19$ \\
\hline \multicolumn{2}{|c|}{ Статистичні } & $\begin{array}{l}\chi^{2}=40,728 \\
\mathrm{p}<0,001 \\
\mathrm{p}<0,05\end{array}$ & $\begin{array}{l}\chi^{2}=29,019 \\
\mathrm{p}<0,001 \\
\mathrm{p}<0,05\end{array}$ & $\begin{array}{l}\chi^{2}=84,638 \\
\mathrm{p}<0,001 \\
\mathrm{p}<0,05\end{array}$ & $\begin{array}{l}\chi^{2}=38,911 \\
\mathrm{p}<0,001 \\
\mathrm{p}<0,05\end{array}$ & $\begin{array}{l}\chi^{2}=2,337 \\
\mathrm{p}=0,127 \\
\mathrm{p}>0,05\end{array}$ \\
\hline
\end{tabular}

Нами проводилось вивчення стану новонароджених дітей від жінок 3 порушенням менструального циклу та жінок контрольної групи. Жінки основної групи народили 71 дитину. У жінок контрольної групи народилось 100 дітей.

Таблиця 4. Розподіл новонароджених дітей за терміном гестації.

\begin{tabular}{|c|c|c|c|c|}
\hline \multirow{3}{*}{\begin{tabular}{|l} 
Група \\
Кількість \\
\end{tabular}} & \multicolumn{2}{|c|}{ Доношені діти } & \multicolumn{2}{|c|}{ Недоношені діти } \\
\hline & \multicolumn{2}{|c|}{ Кількість } & \multicolumn{2}{|c|}{ Кількість } \\
\hline & Абс. & $\%$ & Абс. & $\%$ \\
\hline $\begin{array}{l}\text { Основна } \\
(\Pi=71)\end{array}$ & 55 & 77,5 & 16 & 22,5 \\
\hline $\begin{array}{l}\text { Контрольна } \\
(\Pi=100)\end{array}$ & 81 & 81,0 & 19 & 19,0 \\
\hline $\begin{array}{l}\text { Статистичні } \\
\text { показники }\end{array}$ & \multicolumn{2}{|c|}{$\begin{array}{c}\chi^{2}=0,319 \\
P=0,573 \\
P>0,05\end{array}$} & \multicolumn{2}{|c|}{$\begin{array}{c}\chi^{2}=0,319 \\
P=0,573 \\
P>0,05\end{array}$} \\
\hline
\end{tabular}

Аналіз даних таблиці 4 показав, що переважна більшість дітей народилась доношеними (77,5\% в дослідній групі та 81\% в контрольній). Достовірної різниці 
в кількості доношених та недоношених дітей між двома групами матерів, основної та контрольної, не виявлено (Р>0,05).

\section{Висновки.}

1. Встановлено, що у 72,9\% жінок основної групи та у 62,0\% - контрольної групи спостерігався ускладнений перебіг вагітності (P>0,05).

2. Серед нозологічного спектру ускладнень перебігу вагітності у жінок основної групи найбільшу частку становила загроза переривання I половини вагітності - 14,1\%. У жінок контрольної групи найбільшу частку становила: 8,0\% - загроза переривання I половини вагітності і 7,0\% - поєднання раннього гестозу та загрози переривання I половини вагітності.

3. Встановлено достовірні відмінності між показниками паритету вагітності у жінок основної та контрольної групи для вагітних вперше та IУ і більше разів. Жінки з порушенням менструального циклу не народжували або народжували вперше ( $<0,05)$. Серед 33,7\% жінок основної групи родів не було, перші роди відмічались у 25,2\%, повторні - у 41,1\% жінок. У всіх жінок контрольної групи роди були повторними.

4. При аналізі завершення вагітності встановлено більший відсоток родорозрішень шляхом кесарського розтину у жінок основної групи, що становив 42,3\% у порівнянні 3 19,0\% жінок контрольної групи $(\mathrm{P}<0,05)$. Фізіологічні пологи становили 57,7\% у жінок основної групи та 81,0\% контрольної групи $(\mathrm{P}<0,05)$.

5. Переважна більшість дітей народилась доношеними (77,5\% в дослідній групі та $81 \%$ в контрольній).

Отримані дані потребують подальших досліджень та можуть бути застосовані при формуванні групи ризику репродуктивних втрат серед жінок 3 порушенням менструальної функції у жіночих консультаціях та медикогенетичних центрах (МГЦ) для вдосконалення системи профілактики і ранньої діагностики перинатальної патології, ефективного медико-генетичного консультування та прогнозування здорового потомства. 


\section{Список літератури.}

1. Vitamin D-defitsytni stany $\mathrm{v}$ henezi porushen reproduktyvnoho zdorovia zhinky / T.F. Tatarchuk, K.D. Deiniuk, O.V. Zanko [ta in.] // Reproduktyvna endokrynolohiia. Naukovo-praktychnyi medychnyi zhurnal. 2018. S. 110-124.

2. Hnateiko O.Z., Lukianenko N.S. Ekohenetychni aspekty patolohii liudyny, sprychynenoi vplyvom shkidlyvykh faktoriv zovnishnoho seredovyshcha // Zdorove rebenka. 2007. № 6 (9). S. 82 - 87. 4.

3. Davydova Yu.V., Baranova V.V., Apresova K. H. Psykholohichnyi stan zhinok, yaki vtratyly dytynu abo narodyly dytynu invalida // Zbirnyk naukovykh prats Asotsiatsii akusheriv-hinekolohiv Ukrainy. K.: Intermed. 2011. S. 238-244.

4. Davydova Yu.V., Ohorodnyk A.A. Prekontseptsyonnyi podkhod k profylaktyke vospalytelnykh oslozhnenyi beremennosty // Reproduktyvna endokrynolohiia. Naukovo-praktychnyi medychnyi zhurnal. 2018. S.159-163.

5. Znamenska T.K., Pysariev A.O. Likuvannia herpesvirusnoi infektsii (tsytomehalovirusnoi, neonatalnoho herpesu) u ditei pershoho roku zhyttia iz zastosuvanniam preparatu Flavozidu // Zdorove zhenshchyny. 2009. №4(40). S. 204205.

6. Novi pidkhody do likuvannia vnutrishnoutrobnoi infektsii u novonarodzhenykh vid materiv z bakterialno-virusnymy mikst-infektsiiamy / T.K. Znamenska, L.I. Shevchenko, O.A. Loshak [ta in.] // Neonatolohiia, khirurhiia ta perynatalna medytsyna. 2013. T. III. №2 (8). S. 101-106.

7. Novi pidkhody do profilaktyky nespryiatlyvykh perynatalnykh naslidkiv u zhinok iz nevynoshuvanniam vahitnosti / M.O. Shcherbyna, O.P. Lipko, I.M. Shcherbyna [ta in.] // Aktualni pytannia pediatrii, akusherstva ta hinekolohii. 2019. S. 156-159.

8. Pysariev A.O. Spetsyfichni zminy tsentralnoi nervovoi systemy novonarodzhenykh vid materiv, infikovanykh herpesvirusamy // Sovremennaia pedyatryia. 2013. № 5(53). S. 70-74.

9. Podolskyi V.V. Reproduktyvnoe zdorove zhenshchyn - vazhneishaia problema sovremennosty // Zdorove zhenshchyny. 2013. №1. S. 100-102. 
10. Puty reshenyia problemy perynatalnykh poter / O.V. Hryshchenko, V.V. Bobrytskaia, O.B. Demchenko [ta in.] // Zbirnyk naukovykh prats Asotsiatsii akusheriv-hinekolohiv Ukrainy. K.: Intermed, 2011. S. 205-209.

11. Radzynskyi V.E. Byotsenozy henytalyi pry uhrozhaiushchem nevynashyvanyy y prezhdevremennykh rodakh // Vesnyk RUDN. Medytsyna. 2009. № 6. S. 204-374.

12. Sydelnykov V.M. Nevynashyvanye beremennosty: rukovodstvo dlia praktykuiushchykh vrachei. M.: 000. "Medytsynkkoe ahentstvo". 2011. 536s.

13. Stressovoe besplodye / T.F. Tatarchuk, N.V. Kosei, S.I.Y. Reheda [ta in.] // Reproduktyvna endokrynolohiia. Naukovo-praktychnyi medychnyi zhurnal. 2016. №5(31). S. 12-21.

14. Suchasni pidkhody $\mathrm{v}$ likuvanni nevynoshuvannia vahitnosti / V.V. Kaminskyi, V.V. Konoplianko, M.N. Shalko [ta in.] // Reproduktyvnoe zdorove. 2018, tom 8, №1. S. 24-33.

15. Tatarchuk T.V., Perekhrestenko O.V., Tutchenko T.M. Metabolychnyi syndrom: shcho zminylos za 30 rokiv // Reproduktyvna endokrynolohiia. Naukovopraktychnyi medychnyi zhurnal. 2018. S. 53-69.

16. Foxman B. Urinary tract infection syndromes: occurrence, recurrence, bacteriology, risk factors, and disease burden. Infect. Dis. Clin. North Am., 2014. 28(1): 1-13.

17. TORCH-ynfektsyy $\mathrm{v}$ akusherstve $\mathrm{y}$ neonatolohyy/ pod red. T.K. Znamenskoi. - K.: Standart Digital Print, 2008. 200c.

18. Tregoning J.S. Respiratory Viral Infection in Infants: Causes, Clinical Symptoms, Virology and Immu OAlogy/ J.S. Tregoning, J. Schwarse // Clin. Microbiol.Rev. - 2010. - Vol. 23, № 1. - R. 74-98. 